\title{
Integrated Weed and Nutrient Management Improve Yield, Nutrient Uptake and Economics of Maize in the Rice-Maize Cropping System of Eastern India
}

Dibakar Ghosh ${ }^{1,2, *} \mathbb{D}$, Koushik Brahmachari ${ }^{2}$, Marian Brestic ${ }^{3,4, *} \mathbb{D}$, Peter Ondrisik ${ }^{5}$, Akbar Hossain ${ }^{6, *}{ }^{(0)}$, Milan Skalicky ${ }^{4}\left(\mathbb{D}\right.$, Sukamal Sarkar ${ }^{2,7}{ }^{(0)}$, Debojyoti Moulick ${ }^{8}$, Nirmal Kumar Dinda ${ }^{2,9}$, Anupam Das $\left.{ }^{10}{ }^{(}\right)$, Biswajit Pramanick ${ }^{11}{ }^{\circledR}$, Sagar Maitra ${ }^{12}$ and Richard W. Bell ${ }^{13}$ (D)

1 ICAR-Indian Institute of Water Management, Bhubaneswar 751023, India

2 Department of Agronomy, Bidhan Chandra Krishi Viswavidyalaya, Mohanpur, Nadia 741252, India; brahmacharis@gmail.com (K.B.); sukamalsarkarc@yahoo.com (S.S.); nirmaldinda@gmail.com (N.K.D.)

3 Department of Plant Physiology, Slovak University of Agriculture, Nitra, Tr. A. Hlinku 2, 94901 Nitra, Slovakia

4 Department of Botany and Plant Physiology, Faculty of Agrobiology, Food and Natural Resources, Czech University of Life Sciences Prague, Kamycka 129, 16500 Prague, Czech Republic; skalicky@af.czu.cz

5 Department of Environment and Zoology, Slovak University of Agriculture, Nitra, Tr. A. Hlinku 2, 94901 Nitra, Slovakia; peter.ondrisik@uniag.sk

6 Bangladesh Wheat and Maize Research Institute, Dinajpur 5200, Bangladesh

7 Office of the Assistant Director of Agriculture, Bhagawangola-II Block, Directorate of Agriculture, Government of West Bengal, Murshidabad 742135, India

8 Plant Stress Biology and Metabolomics Laboratory, Assam University, Silchar 788011, India; drubha31@gmail.com

9 Office of the Assistant Director of Agriculture, Suri II Block, Department of Agriculture, Government of West Bengal, Purandapur, Birbhum 731129, India

10 Department of Soil Science and Agricultural Chemistry, Bihar Agricultural University, Sabour 813210, India; anusoil22@gmail.com

11 Department of Agronomy, Dr. Rajendra Prasad Central Agricultural University, Pusa 848125, India; bipra.its4u@gmail.com

12 Department of Agronomy and Agroforestry, Centurion University of Technology and Management, Paralakhemundi 761211, India; sagar.maitra@cutm.ac.in

13 Land Management Group, Agriculture Discipline, Murdoch University, Perth 6150, Australia; r.bell@murdoch.edu.au

* Correspondence: dghoshagro@gmail.com (D.G.); marian.brestic@uniag.sk (M.B.); akbarhossainwrc@gmail.com (A.H.)

Received: 10 November 2020; Accepted: 30 November 2020; Published: 2 December 2020

\begin{abstract}
Increasing productivity of maize while decreasing production costs and maintaining soil health are emerging challenges for the rice-maize system in South Asia. A range of integrated nutrient and weed management practices were tested in winter maize for their effects on yield, profitability, and soil health. The nutrient management treatments were a partial substitution of nitrogen with bulky (Farmyard manure; vermicompost) and concentrated organic manures (Brassicaceous seed meal, BSM; neem cake), whereas weed management practices compared chemical controls only versus an integrated approach. The N supplementation through BSM diminished the weed growth by reducing weed $\mathrm{N}$ uptake, and enhanced the maize crop uptake of nutrients. As compared to the sole chemical approach, atrazine-applied pre-emergence followed by hoeing reduced weed density by 58 and $67 \%$ in years 1 and 2, respectively. The N supplementation through BSM resulted in the maximum yield of maize grain (6.13 and $6.50 \mathrm{t} \mathrm{ha}^{-1}$ in year 1 and year 2, respectively) and this treatment increased yield in year 2 compared to $\mathrm{N}$ application through synthetic fertilizer. Hoeing in conjugation with herbicide enhanced the maize grain yield by $9 \%$ over herbicide alone. The maximum net return and
\end{abstract}


economic efficiency were achieved with the application of BSM for $\mathrm{N}$ supplementation, together with the integrated weed management practice.

Keywords: Brassicaceous seed meal; herbicide; neem cake; nutrient uptake; weed ecology

\section{Introduction}

Maize production is expanding in South Asia as a human food and animal feed. Since it can be grown throughout the year in this environment and due to its high yield potential and strong market demand, maize is replacing areas of winter wheat, monsoon, and winter rice. Moreover, due to less photorespiration ( $\mathrm{C}_{4}$ plant), maize is resilient to changing climatic conditions. In India, maize is grown on $9.2 \mathrm{~m}$ ha, with an annual production of about $24 \mathrm{~m} \mathrm{t}$ [1]. It is mainly grown as a rainy season crop, but during the past few years, winter maize has been expanding in production in India. Now a major cropping system, the rice-maize pattern occupies more than $0.53 \mathrm{~m}$ ha in India [2]. Rice and maize are both high-nutrient-demanding crops. The use of inorganic fertilizers for enhancing food grain production is unavoidable, given that the issue of food security poses challenges from the local to the global scale. Nevertheless, continuous use of inorganic fertilizers over the long-term brings challenges regarding soil health, which cause a yield reduction. Rakshit et al. [3] observed that the continuous use of inorganic fertilizers worsens the soil bio-physicochemical characteristics, such as bulk density, porosity, electrical conductivity, soil organic carbon, available nitrogen, phosphorus and potassium, dehydrogenase activity, microbial biomass carbon, alkaline phosphatase activity, acid phosphatase activity, etc. The inorganic nitrogenous $(\mathrm{N})$ fertilizers are also polluting water bodies (through leaching) as well as posing serious toxic consequences to the food chain. Zhang et al. [4] reported that considerable portions of inorganic $\mathrm{N}$ fertilizer are used to undergo various transformations, such as ammonia volatilization, denitrification and leaching, leading to pollution of the surrounding agro-environment. So, producing crops with higher productivity and profitability while maintaining sustainability is one of the main challenges for agricultural scientist [2].

Organic manures applied in a sequence have been shown to improve the use efficiency of inorganic fertilizers [5]. The use of organic manure provides these benefits, including better soil organic carbon content, increased sequestration of soil carbon [6], improved nitrogen fixation, and reduced harmful greenhouse gas emission [7-10]. The combined use of organic manures and inorganic fertilizers provides a sustainable soil nutrient balance, enhances soil aggregation, and increases moisture retention capacity and soil fertility [11-13]. Among various organic manures, Farmyard manure (FYM), vermicompost, and poultry manure are commonly used organic manures with several advantages, including adding essential plant nutrients. Mustard and neem cake are widely used in crop production as a nutrient source with weed-suppressive ability [14-17].

In crop production, weeds are the major biotic constraints competing for water, nutrient, space and light, resulting in significant yield losses [18,19]. The yield losses associated with various weeds differ in competitive ability as well as agronomic practices for that cropping system [20-23]. Due to crop-weed competition, the yield loss of maize ranges from 51 to $100 \%$ [24,25]. To minimize weed competition, herbicides have become the standard production practice in the world [26-31]. However, sole dependency on herbicides raises serious concerns about environmental pollution, herbicide residues in the food chain, the development of herbicide-resistant weeds, and the deterioration of soil biological health [32-35]. The integration of non-chemical weed management approaches with herbicides not only increases weed control efficiency, but can overcome problems associated with over-reliance on herbicides alone [19].

The different agronomic aspects of land and fertilizer management not only influence crop growth but also manipulate the diversity and growth of associated weeds $[20,21,36]$. Weeds compete with crops for nutrients by absorbing nutrients more rapidly than the crops. The dose and source of 
nutrients, especially nitrogen, will influence the weed community structure [20]. The replacement of inorganic nitrogen fertilizers with organic sources may help in weed management in the rice-maize cropping sequence.

The objective of the study was to formulate a more profitable and sustainable maize production system through integrated weed and nutrient management practices in the alluvial plain region of Eastern India. The specific objectives were: (i) to study the effect of different nutrient sources and weed management practices on growth, productivity, profitability and macronutrient uptake by maize, and (ii) to assess the effects on weed growth and their nutrient uptake under varied treatment combinations.

\section{Materials and Methods}

\subsection{Experimental Site}

The field experiment was conducted during the consecutive winter seasons of 2014-2015 and 2015-2016 in a farmer's field situated at Uttar Chandamari village, Muratipur, Nadia, West Bengal, India $\left(88^{\circ} 27^{\prime} \mathrm{N}\right.$ latitude and $22^{\circ} 59^{\prime} \mathrm{E}$ longitude with the altitude of $7.9 \mathrm{~m}$ above the mean sea level). The experimental site experiences a sub-tropical humid climate with an average annual rainfall of $1400 \mathrm{~mm}$, most of which falls from June to September. The rainfall during the experimental period (November to March) was 24.2 and $73.9 \mathrm{~mm}$ in 2014-2015 and 2015-2016, respectively. During experimentation, the maximum temperature was 37.3 and $35.1^{\circ} \mathrm{C}$, and the minimum was 9.6 and $9.3^{\circ} \mathrm{C}$ in 2014-2015 and 2015-2016, respectively. During November, the temperature starts to fall and remains low until February. The maximum relative humidity was 89 and $95 \%$, and the minimum was 34 and $42 \%$ in 2014-2015 and 2015-2016, respectively. The overall weather conditions were quite favorable for the growth and development of hybrid maize during both the years of experimentation. The soil was Gangetic alluvium (Entisol) type with a sandy clay loam texture. The experiment was conducted on medium-low land with good water holding capacity and moderate soil fertility status. The initial physicochemical properties of the experimental soil have been summarized in Table 1.

Table 1. Physico-chemical properties of initial soil (0-15 $\mathrm{cm}$ depth).

\begin{tabular}{|c|c|c|}
\hline Properties & Value & Methods Followed \\
\hline Sand (\%) & 34.7 & \\
\hline Silt $(\%)$ & 29.2 & Hydrometer method [37] \\
\hline Clay $(\%)$ & 36.1 & \\
\hline Textural class & Clay-loam & Textural triangle [38] \\
\hline $\mathrm{pH}$ & 6.27 & (in 1:2.5-Soil: Water) [39] \\
\hline Electrical conductivity $\left(\mathrm{dS} \mathrm{m}^{-1}\right)$ & 0.19 & (in 1:2.5—Soil: Water) [39] \\
\hline Organic carbon $(\%)$ & 0.52 & Walkley and Black method [39] \\
\hline Available $\mathrm{N}\left(\mathrm{kg} \mathrm{ha}^{-1}\right)$ & 215 & Alkaline Permanganate method [40] \\
\hline Available P (kg ha $\left.{ }^{-1}\right)$ & 36.3 & $0.5 \mathrm{M} \mathrm{NaHCO}_{3}$ extractable [41] \\
\hline Available K (kg ha $\left.{ }^{-1}\right)$ & 173 & $\begin{array}{c}\text { Flame Photometric method (Ammonium } \\
\text { acetate/ } \mathrm{NH}_{4} \mathrm{OAc} \text { extract [42] }\end{array}$ \\
\hline
\end{tabular}

\subsection{Experimental Treatments}

The experiment design was a randomized block design with a factorial combination of nutrient and weed management treatments. The nutrient management practices were as follows: inorganic fertilizer, the combination of inorganic fertilizer with bulky organic manures (FYM and vermicompost) and concentrated organic manures (Brassicaceous seed meal, BSM, and neem cake). Organic sources replaced $25 \%$ of the recommended $\mathrm{N}$ for maize (Table 2). The chemical composition of organic fertilizer is shown in a previously published paper [43]. The weed management treatments were as follows: no weed control, chemical control using atrazine (1000 $\mathrm{g} \mathrm{ha}^{-1}$ as pre-emergence (PRE) at 2 days after sowing (DAS)) and integrated weed management (Atrazine $1000 \mathrm{~g} \mathrm{ha}^{-1}$ as PRE at 2 DAS followed by 
hoeing at 30 DAS). There were three replicates of each treatment. The experiment was conducted for two consecutive years in the same field with the same layout. The recommended dose of fertilizer for maize was 200:49.6:26.2 kg nitrogen (N):phosphorus (P):potassium (K) ha ${ }^{-1}$ [44]. The N, P and K were applied through urea $(46 \% \mathrm{~N})$, single superphosphate $(16 \% \mathrm{P})$ and muriate of potash $(60 \% \mathrm{~K})$. The full amounts of $\mathrm{P}$ and $\mathrm{K}$ fertilizers along with $1 / 2 \mathrm{~N}$ were applied before the sowing of maize seed. The remaining $1 / 2 \mathrm{~N}$ was applied in two equal splits at the knee-height stage and pre-tasseling stage. All the organic manures were applied two days before the final land preparation. The herbicides were applied with a 16-litre knapsack sprayer with flat fan nozzles, and the spray volume was maintained at $500 \mathrm{~L} \mathrm{ha}^{-1}$. For mechanical weed removal, a wheel hoe was used at $30 \mathrm{DAS}$, and in the herbicide control plot, no weed removal was done.

Table 2. Nutrient and weed management treatments used in this study.

\begin{tabular}{|c|c|c|c|}
\hline Treatments & $\begin{array}{l}\text { Treatment } \\
\text { Annotation }\end{array}$ & Treatment Details & Remarks \\
\hline \multirow{5}{*}{ Nutrient Management } & $\mathrm{NM}_{1}$ & $100 \% \mathrm{RD}_{\mathrm{NPK}}$ & Inorganic nutrient \\
\hline & $\mathrm{NM}_{2}$ & $\begin{array}{c}100 \% \mathrm{RD}_{\mathrm{PK}}+75 \% \mathrm{RD}_{\mathrm{N}}+25 \% \mathrm{~N} \\
\text { (Vermicompost) }\end{array}$ & \multirow{2}{*}{$\begin{array}{l}\text { Integrated nutrient } \\
\text { management with bulky } \\
\text { organic manure }\end{array}$} \\
\hline & $\mathrm{NM}_{3}$ & $100 \% \mathrm{RD}_{\mathrm{PK}}+75 \% \mathrm{RD}_{\mathrm{N}}+25 \% \mathrm{~N}(\mathrm{FYM})$ & \\
\hline & $\mathrm{NM}_{4}$ & $100 \% \mathrm{RD}_{\mathrm{PK}}+75 \% \mathrm{RD}_{\mathrm{N}}+25 \% \mathrm{~N}(\mathrm{BSM})$ & \multirow{2}{*}{$\begin{array}{c}\text { Integrated nutrient } \\
\text { management with } \\
\text { concentrated organic manure }\end{array}$} \\
\hline & $\mathrm{NM}_{5}$ & $\begin{array}{c}100 \% \mathrm{RD}_{\mathrm{PK}}+75 \% \mathrm{RD}_{\mathrm{N}}+25 \% \mathrm{~N} \\
\text { (Neemcake) }\end{array}$ & \\
\hline \multirow{3}{*}{ Weed Management } & $\mathrm{WM}_{1}$ & Weedy & \\
\hline & $\mathrm{WM}_{2}$ & Atrazine $1000 \mathrm{~g} /$ ha at 2 DAS & \\
\hline & $\mathrm{WM}_{3}$ & $\begin{array}{c}\text { Atrazine } 1000 \mathrm{~g} / \mathrm{ha} \text { at } 2 \mathrm{DAS} \text { followed by } \\
\text { hoeing at } 30 \mathrm{DAS}\end{array}$ & \\
\hline
\end{tabular}

RD, Recommended dose through fertilizer; N, Nitrogen; P, Phosphorus; K, Potassium; FYM, Farmyard manure; BSM, Brassicaceous seed meal.

\subsection{Crop Management}

The hybrid maize (cv. P-3396) crop was manually sown on the 10th and 7th day of November 2014 and 2015, respectively, at a row to row and plant to plant distance of 60 and $30 \mathrm{~cm}$, respectively. Individual plots were $21.6 \mathrm{~m}^{2}(7.2 \times 3 \mathrm{~m})$ and separated by a $1.0 \mathrm{~m}$ gap from the adjacent plots. After sowing, irrigation was performed for uniform germination, and subsequently, four irrigations were applied at the knee-height, tasseling, silking and grain-filling stages during year 1, and three irrigations were applied at the knee-height, tasseling and grain-filling stages during year 2 . Fipronil $5 \%$ SC (RegentSC) was sprayed for controlling stem borer and other related insects. The biometric observations and destructive plant sampling were performed from the second row on either side of each plot, whereas for the determination of yield, the middle eight rows were marked. The maize crop was harvested manually on 22 and 20 of March 2015 and 2016, respectively.

\subsection{Measurements and Analytical Procedure}

For weed density and weed dry biomass accumulation at 60 DAS, two permanent quadrats were installed in each plot after maize sowing. Weed density was measured as the number of weeds per $\mathrm{m}^{2}$ at 60 DAS from two permanent quadrats. Weeds from two quadrats were cut at ground level for measuring weed dry weight data $\left(\mathrm{g} \mathrm{m}^{-2}\right)$. For taking dry weight, the harvested weed samples were first washed in clean tap water, then sun-dried and finally oven-dried at $70{ }^{\circ} \mathrm{C}$ for $48 \mathrm{~h}$ and weighed. The plant dry matter accumulation was measured from five plants, and cut at ground level from the second row on either side, as marked for destructive plant sampling. The plant samples were dried in an oven at $70{ }^{\circ} \mathrm{C}$ temperature for $48 \mathrm{hrs}$ before weighed. For grain yield, cobs from plants of the middle eight rows were harvested and grains were removed from the cob. The grain yield was adjusted for $14.0 \%$ moisture content. 
From each treatment, the weed (at 60 DAS) and crop (at harvest) samples were oven-dried, and ground for analyzing the total contents of N, P and K. Nitrogen was estimated by the micro-Kjeldahl method. For the determination of $\mathrm{P}$ and $\mathrm{K}$ contents, plant (weed/crop) material was digested in a tri-acid mixture $\left(\mathrm{HNO}_{3}: \mathrm{H}_{2} \mathrm{SO}_{4}: \mathrm{HClO}_{4}=10: 1: 4\right)[40]$ and estimated by spectrophotometer and flame photometer, respectively.

The general cost of maize cultivation was estimated considering all costs incurred during maize production, excluding the cost of weed and nutrient management. The variable cost included the cost of integrated nutrient management practices based on average retail prices in West Bengal (India) for the respective experimental years. The total monetary returns (gross return) of the economic produce obtained from the crops were calculated based on minimum support prices (MSP) from the Government of India for hybrid maize grains of the respective years [45]. The gross return is expressed on a per hectare basis using the following equation:

$$
\text { Gross return }=\text { Grain yield } \times \text { MSP }
$$

Net return per hectare basis was calculated by subtracting the total cost of cultivation from the gross returns.

\subsection{Statistical Analysis}

The data were analyzed using SAS Windows Version 9.3 (SAS Institute Inc., Cary, NC, USA). The data were subjected to 2-way analysis of variance. Due to high variance, actual weed density was transformed by square root transformation for statistical analysis. The effect of the years was significant, and all experimental data were presented year-wise. Treatment means were separated with the use of Tukey's Honestly Significant Difference test at the 5\% level of significance. The benefit:cost ratio (B:C ratio) was calculated according to [46]. The Excel software (version 2016, Microsoft Inc., Redmond, WA, USA) was used to draw graphs and figures.

\section{Results}

\subsection{Weed Growth}

The weed species observed in the maize study were Anagallis arvensis L., Cyperus rotundus L., Alternanthera philoxeroides (Mart.) Griseb., Vicia hirsuta (L.) Gray and Launaea aspleniifolia (Willd.) Hook.f. The weed density, dry matter accumulation and nutrient uptake by weeds are influenced by nutrient and weed management practices, as described in Table 3. During the initial year, the sources of nutrients as organic or inorganic did not have any significant impact on total weed density at 60 DAS in maize, but in year 2, the density of weeds was significantly reduced with the application BSM and neem cake for $\mathrm{N}$ supplementation. The concentrated organic manures (BSM and neem cake), as well as acting as a nutrient source, also reduced the total weed density by $\sim 16$ and $13 \%$ as compared to the sole synthetic fertilizer and bulky organic manures (FYM and vermicompost), respectively. Under the weedy situation, the application of BSM reduced the total weed density in year 1; however, the repeated addition of neem cake performed better in reducing total weed density in year 2 . Hoeing at 30 DAS following atrazine PRE reduced the weed density by 58 and $67 \%$ in year 1 and 2, respectively, compared to the sole atrazine application. On the other hand, atrazine-applied PRE diminished the total weed density by 78 and $81 \%$ in year 1 and 2, respectively, as compared to the untreated. 
Table 3. Interactive effect of different nutrient sources and weed management practices on weed growth, nutrient uptake and grain yield in maize.

\begin{tabular}{|c|c|c|c|c|c|c|c|c|c|c|}
\hline \multirow{3}{*}{ Treatment } & \multicolumn{4}{|c|}{ Weed Growth } & \multirow{2}{*}{\multicolumn{2}{|c|}{ N Uptake (kg ha- $\left.{ }^{-1}\right)$ by Weeds }} & \multirow{2}{*}{\multicolumn{2}{|c|}{ Dry Matter Accumulation (kg ha $\left.{ }^{-1}\right)$}} & \multirow{2}{*}{\multicolumn{2}{|c|}{ Grain Yield $\left(t \mathrm{ha}^{-1}\right)$}} \\
\hline & \multicolumn{2}{|c|}{ Weed Density (no. $\mathrm{m}^{-2}$ ) } & \multicolumn{2}{|c|}{ Weed Dry Weight $\left(\mathrm{g} \mathrm{m}^{-2}\right.$ ) } & & & & & & \\
\hline & Year 1 & Year 2 & Year 1 & Year 2 & Year 1 & Year 2 & Year 1 & Year 2 & Year 1 & Year 2 \\
\hline $\mathrm{NM}_{1} \times \mathrm{WM}_{1}$ & $46.9\left(2196^{\#}\right)$ & $41.2(1695)$ & 277.2 & 140.9 & 78.8 & 39.0 & 736 & 627 & 4.30 & 4.39 \\
\hline$\times \mathrm{WM}_{2}$ & $19.4(376)$ & $14.6(214)$ & 91.1 & 45.8 & 23.9 & 11.2 & 1391 & 1433 & 5.85 & 5.99 \\
\hline$\times \mathrm{WM}_{3}$ & $12.4(154)$ & $8.7(74)$ & 25.0 & 12.4 & 5.95 & 2.76 & 1914 & 1970 & 6.44 & 6.60 \\
\hline $\mathrm{NM}_{2} \times \mathrm{WM}_{1}$ & $42.7(1820)$ & $39.9(1588)$ & 234.3 & 161.4 & 66.6 & 44.9 & 771 & 793 & 4.17 & 4.26 \\
\hline$\times \mathrm{WM}_{2}$ & $21.4(455)$ & $16.3(264)$ & 102.5 & 45.7 & 26.5 & 11.5 & 1726 & 1778 & 6.15 & 6.61 \\
\hline$\times \mathrm{WM}_{3}$ & $13.2(174)$ & $9.6(91)$ & 21.6 & 15.4 & 5.42 & 3.65 & 2055 & 2115 & 6.35 & 6.82 \\
\hline $\mathrm{NM}_{3} \times \mathrm{WM}_{1}$ & $46.2(2136)$ & $35.9(1288)$ & 246.1 & 125.3 & 69.8 & 34.4 & 719 & 741 & 4.36 & 5.37 \\
\hline$\times \mathrm{WM}_{2}$ & $18.4(340)$ & $17.0(288)$ & 105.0 & 43.9 & 27.9 & 10.7 & 1668 & 1718 & 5.94 & 6.77 \\
\hline$\times \mathrm{WM}_{3}$ & $12.0(144)$ & $9.2(84)$ & 23.0 & 17.4 & 5.68 & 4.08 & 2260 & 2324 & 6.55 & 6.65 \\
\hline $\mathrm{NM}_{4} \times \mathrm{WM}_{1}$ & $39.8(1581)$ & $31.8(1013)$ & 235.1 & 107.1 & 65.8 & 28.9 & 781 & 804 & 4.93 & 5.04 \\
\hline$\times \mathrm{WM}_{2}$ & $22.7(517)$ & $14.1(197)$ & 99.5 & 25.5 & 26.7 & 5.94 & 1551 & 1964 & 5.96 & 7.06 \\
\hline$\times \mathrm{WM}_{3}$ & $14.1(200)$ & $8.6(74)$ & 34.2 & 11.3 & 8.20 & 2.45 & 2283 & 2351 & 7.83 & 8.07 \\
\hline $\mathrm{NM}_{5} \times \mathrm{WM}_{1}$ & 44.1 (1946) & $29.5(869)$ & 243.6 & 109.1 & 68.1 & 29.6 & 646 & 665 & 4.61 & 5.12 \\
\hline$\times \mathrm{WM}_{2}$ & $20.1(405)$ & $15.0(225)$ & 113.6 & 33.4 & 28.9 & 8.17 & 1701 & 1933 & 6.41 & 7.07 \\
\hline$\times \mathrm{WM}_{3}$ & $14.2(201)$ & $8.4(70)$ & 51.4 & 13.6 & 13.1 & 3.13 & 2002 & 2061 & 6.85 & 7.36 \\
\hline SEm \pm & 2.04 & 1.26 & 24.8 & 9.6 & 7.11 & 2.68 & 179 & 152 & 0.33 & 0.34 \\
\hline $\mathrm{CD}(p \leq 0.05)$ & 5.92 & 3.64 & 71.9 & 27.8 & 20.6 & 7.77 & 519 & 440 & 0.99 & 0.97 \\
\hline & & & & & Source of $\mathrm{v}$ & & & & & \\
\hline NM & ns & $* * *$ & ns & * & ns & $*$ & ns & ns & ns & $* *$ \\
\hline WM & $* * *$ & $* * *$ & $* * *$ & $* * *$ & $* * *$ & $* * *$ & $* * *$ & $* * *$ & $* * *$ & $* * *$ \\
\hline $\mathrm{NM} \times \mathrm{WM}$ & $*$ & $* * *$ & $*$ & $*$ & $*$ & $*$ & $*$ & $*$ & $*$ & $*$ \\
\hline
\end{tabular}

$\mathrm{NM}$, nutrient management; WM, weed management; $\mathrm{NM}_{1}, 100 \% \mathrm{RD}_{\mathrm{NPK}} ; \mathrm{NM}_{2}, 100 \% \mathrm{RD}_{\mathrm{PK}}+75 \% \mathrm{RD}_{\mathrm{N}}+25 \% \mathrm{~N}$ (vermicompost); $\mathrm{NM}_{3}, 100 \% \mathrm{RD}$ PK $+75 \% \mathrm{RD}$ N $+25 \% \mathrm{~N}(\mathrm{FYM}) ; \mathrm{NM}_{4}$,

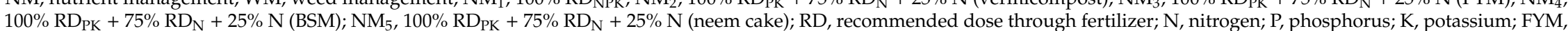
farmyard manure; $\mathrm{BSM}$, Brasecacious seed meal; $\mathrm{WM}_{1}$, weedy; $\mathrm{WM}_{2}$, atrazine $1000 \mathrm{~g}$ /ha at 2 DAS; $\mathrm{WM}_{3}$, atrazine $1000 \mathrm{~g} /$ ha at 2 DAS followed by hoeing at $30 \mathrm{DAS} ;$ Year 1 and Year 2 represents winter seasons of 2014-2015 and 2015-2016, respectively; ns, non-significant $(p>0.05) ;{ }^{*}, * *$ and ${ }^{* * *}$ indicate significant at $p<0.05,0.01$ and 0.001 , respectively; ${ }^{*}$ Original data in parentheses were subjected to square-root transformation $\sqrt{(x+0.5)}$ before statistical analysis 
The weed dry biomass was minimal in BSM-applied plots, and significantly lower than in plots treated with sole chemical fertilizer $\left(100 \% \mathrm{RD}_{\mathrm{NPK}}\right)$ or vermicompost-applied plots in year 2 . The addition of concentrated organic manure (BSM and vermicompost) over years had a cumulative effect in suppressing the weed growth in the second year of study, compared to the large amount of organic manure or to the inorganic fertilizer. Among weed management practices, sole atrazine application reduced the total weed dry biomass by 57 and $70 \%$ in year 1 and 2, respectively, over the untreated plot. Hoeing plus atrazine PRE was superior $(p<0.05)$ over atrazine PRE alone in reducing weed biomass at 60 DAS in both the years of study. The addition of mechanical weeding following atrazine PRE enhanced the weed control index by 70 and $64 \%$ in year 1 and 2, respectively, compared to atrazine PRE alone.

Different sources of nutrients (organic and inorganic) influenced the $\mathrm{N}$ uptake by weeds only in the second year (Table 3). Nitrogen supplementation with BSM was more efficient in reducing the $\mathrm{N}$ uptake by weeds in the maize crop as compared to ' $N$ ' application through inorganic fertilizer $\left(100 \% \mathrm{RD}_{\mathrm{NPK}}\right)$ and neem cake. Both weed management practices significantly reduced the $\mathrm{N}$ uptake by weeds through the removal of weeds. The combination of a PRE-herbicide with mechanical weeding significantly reduced weed growth and restricted $\mathrm{N}$ removal by different weeds compared to the atrazine alone.

\subsection{Crop Growth}

The different nutrient sources had no significant impact on plant dry matter accumulation in the first year of study, but in the following year, BSM alone significantly augmented the dry matter of the maize plant compared to sole inorganic fertilization (Table 3). Both weed management practices significantly increased maize biomass over the check. The maize plant biomass was higher in the atrazine plus hoeing than the atrazine alone. Under sole atrazine-applied plots, repeated applications of concentrated organic manures as the nutrient source augmented the growth of the maize plant compared to the inorganic fertilizer.

The highest maize grain yield was recorded with BSM-applied plots (6.13 and $6.50 \mathrm{t} \mathrm{ha}^{-1}$ in year 1 and year 2, respectively), and this was significantly higher than the sole inorganic fertilizer in year 2 . The addition of concentrated organic manures as a nutrient source enhanced the maize grain yield by 14 and $9 \%$ over sole inorganic fertilizer and bulky organic manures, respectively. Weed management practices, atrazine alone and atrazine followed by hoeing produced 37 and $49 \%$ higher maize grain yields, respectively, as compared to check. The addition of hoeing improved the maize grain production by $9 \%$ over atrazine alone. Among different treatment combinations, the maize yield in both years of the study for the plot receiving BSM for N supplementation and atrazine followed by hoeing as the weed management practice was the highest.

\subsection{Nutrients Uptake by Maize}

The nutrient uptakes by grain and stover of the maize plant, influenced by the nutrient and weed management practices, are described in Table 4. The N supplementation through BSM maximized grain $\mathrm{N}$ uptake. On the other hand, $\mathrm{N}$ supplementation through neem cake significantly enhanced the $\mathrm{P}$ uptake by maize grain, whereas the lowest $\mathrm{P}$ uptake by maize grain was observed with $\mathrm{N}$ supplementation through vermicompost. In the case of stover, the lowest $\mathrm{N}$ and $\mathrm{P}$ uptake was observed when $\mathrm{N}$ was supplemented through vermicompost, and the maximum $\mathrm{K}$ uptake by maize grain was observed from BSM- and FYM-applied plots in year 1 and year 2, respectively. The application of BSM and vermicompost as organic sources maximized the $\mathrm{K}$ uptake by maize stover in year 1 and year 2, respectively. During the first year of experimentation, $\mathrm{N}$ supplementation through organic manures had a non-significant $(p \geq 0.05)$ impact on total $\mathrm{N}$ uptake by the maize plant, whereas during the second year the application of BSM resulted in significantly $(p \leq 0.001)$ higher $\mathrm{N}$ uptake by maize plant. However, the $\mathrm{N}$ harvest index was not influenced by nutrient supplementation through organic manures. The chemical and integrated weed management practices significantly increased N, P and K uptake by maize grain and stover, along with the total $\mathrm{N}$ uptake by maize plant and $\mathrm{N}$ harvest index in both years. 
Table 4. Interaction effect of different nutrient sources and weed management practices on nutrients in hybrid maize.

\begin{tabular}{|c|c|c|c|c|c|c|c|c|c|c|c|c|c|c|c|c|}
\hline \multirow{3}{*}{ Treatment } & \multicolumn{4}{|c|}{ N Uptake (kg ha-1) } & \multirow{2}{*}{\multicolumn{2}{|c|}{$\mathrm{N}$ total Uptake ( $\left.\mathrm{kg} \mathrm{ha}^{-1}\right)$}} & \multirow{2}{*}{\multicolumn{2}{|c|}{ N Harvest Index }} & \multicolumn{4}{|c|}{ P Uptake (kg ha-1) } & \multicolumn{4}{|c|}{ K Uptake (kg ha-1) } \\
\hline & \multicolumn{2}{|c|}{ Grain } & \multicolumn{2}{|c|}{ Stover } & & & & & \multicolumn{2}{|c|}{ Grain } & \multicolumn{2}{|c|}{ Stover } & \multicolumn{2}{|c|}{ Grain } & \multicolumn{2}{|c|}{ Stover } \\
\hline & Year 1 & Year 2 & Year 1 & Year 2 & Year 1 & Year 2 & Year 1 & Year 2 & Year 1 & Year 2 & Year 1 & Year 2 & Year 1 & Year 2 & Year 1 & Year 2 \\
\hline $\mathrm{NM}_{1} \times \mathrm{WM}_{1}$ & 83.0 & 76.1 & 94.1 & 91.8 & 177 & 168 & 0.468 & 0.453 & 8.7 & 8.9 & 19.8 & 14.7 & 50.0 & 28.2 & 82.6 & 72.9 \\
\hline$\times \mathrm{WM}_{2}$ & 108.2 & 110.6 & 86.1 & 78.9 & 194 & 190 & 0.557 & 0.585 & 8.3 & 12.8 & 13.8 & 11.6 & 75.0 & 76.7 & 62.6 & 62.8 \\
\hline$\times \mathrm{WM}_{3}$ & 110.3 & 113.1 & 108.0 & 112.4 & 218 & 226 & 0.505 & 0.502 & 14.8 & 15.2 & 23.7 & 24.7 & 58.5 & 60.0 & 111.7 & 92.8 \\
\hline $\mathrm{NM}_{2} \times \mathrm{WM}_{1}$ & 78.3 & 79.9 & 71.8 & 78.6 & 150 & 159 & 0.525 & 0.501 & 6.9 & 7.0 & 14.9 & 16.3 & 46.8 & 47.8 & 71.3 & 78.1 \\
\hline$\times \mathrm{WM}_{2}$ & 108.5 & 129.9 & 88.0 & 89.7 & 196 & 220 & 0.554 & 0.590 & 10.8 & 11.6 & 18.5 & 18.8 & 72.3 & 50.6 & 68.7 & 92.9 \\
\hline$\times \mathrm{WM}_{3}$ & 106.7 & 114.5 & 90.5 & 104.6 & 197 & 219 & 0.541 & 0.523 & 9.1 & 14.6 & 17.1 & 18.2 & 72.6 & 78.0 & 113.8 & 121.3 \\
\hline $\mathrm{NM}_{3} \times \mathrm{WM}_{1}$ & 69.6 & 89.2 & 91.4 & 95.9 & 161 & 185 & 0.433 & 0.484 & 7.5 & 9.2 & 16.7 & 17.6 & 50.7 & 87.7 & 80.3 & 84.3 \\
\hline$\times \mathrm{WM}_{2}$ & 113.0 & 128.8 & 102.8 & 112.7 & 216 & 241 & 0.523 & 0.535 & 12.5 & 14.2 & 12.2 & 20.3 & 67.0 & 76.3 & 73.3 & 75.0 \\
\hline$\times \mathrm{WM}_{3}$ & 123.0 & 117.1 & 93.1 & 91.2 & 216 & 208 & 0.569 & 0.562 & 12.2 & 13.2 & 14.7 & 22.2 & 79.9 & 79.7 & 76.5 & 90.6 \\
\hline $\mathrm{NM}_{4} \times \mathrm{WM}_{1}$ & 93.9 & 96.0 & 104.3 & 95.1 & 198 & 191 & 0.473 & 0.501 & 10.8 & 11.0 & 20.8 & 11.9 & 62.9 & 64.3 & 86.7 & 79.1 \\
\hline$\times \mathrm{WM}_{2}$ & 110.2 & 140.2 & 78.9 & 126.1 & 189 & 266 & 0.584 & 0.527 & 10.6 & 12.5 & 13.3 & 16.5 & 71.3 & 67.6 & 68.4 & 92.4 \\
\hline$\times \mathrm{WM}_{3}$ & 140.4 & 144.7 & 112.1 & 112.4 & 252 & 257 & 0.556 & 0.563 & 9.8 & 17.2 & 15.5 & 24.4 & 68.2 & 70.3 & 117.1 & 91.4 \\
\hline $\mathrm{NM}_{5} \times \mathrm{WM}_{1}$ & 72.2 & 86.0 & 77.1 & 78.9 & 149 & 165 & 0.484 & 0.524 & 13.2 & 11.1 & 19.9 & 13.7 & 53.8 & 59.7 & 75.2 & 76.9 \\
\hline$\times \mathrm{WM}_{2}$ & 114.9 & 135.7 & 106.8 & 104.5 & 222 & 240 & 0.526 & 0.573 & 9.6 & 13.8 & 14.4 & 22.5 & 54.9 & 60.5 & 89.0 & 71.5 \\
\hline$\times \mathrm{WM}_{3}$ & 120.9 & 123.4 & 80.4 & 91.5 & 201 & 215 & 0.600 & 0.575 & 18.7 & 20.1 & 23.3 & 26.5 & 81.9 & 70.5 & 64.3 & 73.1 \\
\hline $\mathrm{SEm} \pm$ & 5.99 & 6.32 & 8.17 & 8.4 & 12.6 & 10.3 & 0.017 & 0.024 & 0.66 & 0.68 & 1.45 & 1.68 & 3.75 & 3.72 & 7.26 & 6.54 \\
\hline $\mathrm{CD}(p \leq 0.05)$ & 17.4 & 18.3 & 23.7 & 24.2 & ns & 30 & 0.049 & ns & 1.92 & 1.98 & 4.21 & 4.88 & 10.9 & 10.8 & 21.0 & 18.9 \\
\hline \multicolumn{17}{|c|}{ Source of variation } \\
\hline NM & $*$ & $* * *$ & ns & * & ns & $* * *$ & ns & ns & $* * *$ & $* * *$ & $* *$ & $*$ & ns & $* * *$ & ns & $* * *$ \\
\hline WM & $* * *$ & $* * *$ & ns & $*$ & $* * *$ & $* * *$ & $* * *$ & $* * *$ & $* * *$ & $* * *$ & $* * *$ & $* * *$ & $* * *$ & $* * *$ & $* * *$ & $* * *$ \\
\hline $\mathrm{NM} \times \mathrm{WM}$ & $*$ & ns & $*$ & * & ns & $*$ & $* *$ & ns & $* * *$ & $* *$ & $* *$ & $* *$ & $* * *$ & $* * *$ & $* * *$ & $*$ \\
\hline
\end{tabular}

$\mathrm{NM}$, nutrient management; $\mathrm{WM}$, weed management; $\mathrm{NM}_{1}, 100 \% \mathrm{RD}_{\mathrm{NPK}} ; \mathrm{NM}_{2}, 100 \% \mathrm{RD}_{\mathrm{PK}}+75 \% \mathrm{RD}_{\mathrm{N}}+25 \% \mathrm{~N}$ (vermicompost); $\mathrm{NM}_{3}, 100 \%$ RD $\mathrm{PK}+75 \%$ RD $+25 \% \mathrm{~N}(\mathrm{FYM}) ; \mathrm{NM}_{4}$ $100 \% \mathrm{RD}$ PK $+75 \% \mathrm{RD}_{\mathrm{N}}+25 \% \mathrm{~N}$ (BSM); $\mathrm{NM}_{5}, 100 \% \mathrm{RD} \mathrm{PK}+75 \% \mathrm{RD}_{\mathrm{N}}+25 \% \mathrm{~N}$ (neem cake); RD, recommended dose through fertilizer; $\mathrm{N}$, nitrogen; P, phosphorus; K, potassium; FYM, farmyard manure; $\mathrm{BSM}$, Brasecacious seed meal; $\mathrm{WM}_{1}$, weedy; $\mathrm{WM}_{2}$, atrazine $1000 \mathrm{~g} /$ ha at $2 \mathrm{DAS} ; \mathrm{WM}_{3}$, atrazine $1000 \mathrm{~g} /$ ha at $2 \mathrm{DAS}$ followed by hoeing at $30 \mathrm{DAS}$; Year 1 and Year 2 represents winter seasons of 2014-2015 and 2015-2016, respectively; ns, non-significant $(p>0.05) ;{ }^{*}, * *$ and ${ }^{* * *}$ indicate significant at $p<0.05,0.01$ and 0.001, respectively 
The integration of PRE-herbicide with hoeing at 30 DAS statistically enhanced the $\mathrm{N}$ uptake by maize grain and stover over sole atrazine application in year 1 . As regards $\mathrm{P}$ and $\mathrm{K}$ content in maize grain and stover, the addition of hoeing following atrazine enhanced $\mathrm{P}$ and $\mathrm{K}$ content compared to sole atrazine application. However, in both years, the total $\mathrm{N}$ uptake by maize plant and $\mathrm{N}$ harvest index were not augmented significantly with the addition of hoeing over PRE-herbicide.

\subsection{Economics}

Among the different nutrient management treatments applied to maize, the application of $\mathrm{N}$ through inorganic fertilizer had the lowest treatment cost, whereas $25 \% \mathrm{~N}$ supplementation through neem cake had the maximum treatment cost (Table 5). On the other hand, as compared to the atrazine alone, the integration of atrazine and hoeing produced higher net returns in both the years of experiment. The maximum net return and economic efficiency were achieved with the application of BSM for N supplementation and atrazine, followed by hoeing as a weed management practice, and the combination of FYM for $\mathrm{N}$ supplementation and integrated weed management practices closely followed it. The maize grain yield and economic efficiency were highly correlated (0.844). The maximum B:C ratio was obtained with sole inorganic fertilizer as a nutrient source and the integration of herbicide with hoeing for weed management in maize.

Table 5. Economics for maize production/hectare (Based on mean data of two years).

\begin{tabular}{|c|c|c|c|c|c|}
\hline $\begin{array}{c}\text { Treatment } \\
\text { Combinations }\end{array}$ & $\begin{array}{l}\text { Additional Cost } \\
\text { Due to Treatment } \\
\left.\text { (USD ha }{ }^{-1}\right)\end{array}$ & $\begin{array}{l}\text { Gross Return } \\
\text { (USD ha }^{-1} \text { ) }\end{array}$ & $\begin{array}{l}\text { Net Return } \\
\text { (USD ha-1) }\end{array}$ & B:C Ratio & $\begin{array}{l}\text { Economic Efficiency } \\
\text { (USD/Day/ha) }\end{array}$ \\
\hline $\mathrm{NM}_{1} \times \mathrm{WM}_{1}$ & 147 & 1261 & 548 & 1.77 & 4.17 \\
\hline$\times \mathrm{WM}_{2}$ & 206 & 1658 & 928 & 2.27 & 7.06 \\
\hline$\times \mathrm{WM}_{3}$ & 191 & 1814 & 1025 & 2.30 & 7.80 \\
\hline $\mathrm{NM}_{2} \times \mathrm{WM}_{1}$ & 208 & 1202 & 428 & 1.55 & 3.26 \\
\hline$\times \mathrm{WM}_{2}$ & 267 & 1710 & 919 & 2.16 & 6.99 \\
\hline$\times \mathrm{WM}_{3}$ & 191 & 1841 & 990 & 2.16 & 7.53 \\
\hline $\mathrm{NM}_{3} \times \mathrm{WM}_{1}$ & 208 & 1321 & 546 & 1.71 & 4.16 \\
\hline$\times \mathrm{WM}_{2}$ & 267 & 1732 & 941 & 2.19 & 7.16 \\
\hline$\times \mathrm{WM}_{3}$ & 344 & 1880 & 1030 & 2.21 & 7.83 \\
\hline $\mathrm{NM}_{4} \times \mathrm{WM}_{1}$ & 362 & 1428 & 500 & 1.54 & 3.80 \\
\hline$\times \mathrm{WM}_{2}$ & 421 & 1801 & 856 & 1.91 & 6.51 \\
\hline$\times \mathrm{WM}_{3}$ & 465 & 2109 & 1105 & 2.10 & 8.40 \\
\hline $\mathrm{NM}_{5} \times \mathrm{WM}_{1}$ & 482 & 1380 & 331 & 1.32 & 2.51 \\
\hline$\times \mathrm{WM}_{2}$ & 541 & 1812 & 746 & 1.70 & 5.67 \\
\hline$\times \mathrm{WM}_{3}$ & 147 & 1911 & 787 & 1.70 & 5.99 \\
\hline
\end{tabular}

$\mathrm{NM}_{1}, 100 \% \mathrm{RD}_{\mathrm{NPK}} ; \mathrm{NM}_{2}, 100 \% \mathrm{RD}_{\mathrm{PK}}+75 \% \mathrm{RD}_{\mathrm{N}}+25 \% \mathrm{~N}$ (vermicompost); $\mathrm{NM}_{3}, 100 \% \mathrm{RD}_{\mathrm{PK}}+75 \% \mathrm{RD}_{\mathrm{N}}+25 \%$ $\mathrm{N}(\mathrm{FYM}) ; \mathrm{NM}_{4}, 100 \% \mathrm{RD}_{\mathrm{PK}}+75 \% \mathrm{RD}_{\mathrm{N}}+25 \% \mathrm{~N}(\mathrm{BSM}) ; \mathrm{NM}_{5}, 100 \% \mathrm{RD}_{\mathrm{PK}}+75 \% \mathrm{RD}_{\mathrm{N}}+25 \% \mathrm{~N}$ (neem cake); $\mathrm{RD}$, recommended dose through fertilizer; N, nitrogen; $\mathrm{P}$, phosphorus; $\mathrm{K}$, potassium; FYM, farmyard manure; BSM, Brasecacious seed meal; $\mathrm{WM}_{1}$, weedy; $\mathrm{WM}_{2}$, atrazine $1000 \mathrm{~g} / \mathrm{ha}$ at $2 \mathrm{DAS} ; \mathrm{WM}_{3}$, atrazine $1000 \mathrm{~g} / \mathrm{ha}$ at $2 \mathrm{DAS}$ followed by hoeing at 30 DAS; DAS, days after sowing. Cost of urea: $0.107 \mathrm{USD} \mathrm{kg}^{-1}$; Single super phosphate (SSP): $0.114 \mathrm{USD} \mathrm{kg}^{-1}$; Muriate of potash (MOP): $0.257 \mathrm{USD} \mathrm{kg}^{-1}$; Vermicompost (VC): $0.021 \mathrm{USD} \mathrm{kg}^{-1}$; Farmyard manure (FYM): 0.009 USD kg-1; Brassicaceous seed meal (BSM): $0.214 \mathrm{USD} \mathrm{kg}^{-1}$; Neem cake (NC): $0.357 \mathrm{USD} \mathrm{kg}^{-1}$; Labor wages @ 2.57 USD man unit ${ }^{-1}$; Cost of atrazine: 12.53 USD kg $^{-1}$; 1 USD (US dollar) D 70 Indian Rupees.

\section{Discussion}

The rice-maize cropping system is rapidly expanding in India and Bangladesh, driven by demand for maize, especially by the poultry/fish sector, and world export-import markets [2]. Along with wheat and rice, maize provides $\sim 30 \%$ of the calorific demand to around 4.5 billion people in 94 developing countries. These populations include 900 million consumers living below or at the poverty line who prefer maize as a staple food. Maize is currently cultivated in almost 100 million hectares spanning across 125 developing countries [47]. According to an observation made by Rosegrant et al. [48], the world population will be 9.3 billion, and maize is expected to double in production in developing countries, by 2050. Due to its high grain and stover yields, nutrient management for maize needs the appropriate integration approach of inorganic fertilizer with organic manures. On the other hand, 
integrated weed management strategies in maize production systems are still lacking in South Asian countries. The present research identified an integrated weed and nutrient management strategy to enhance maize yield for the emerging rice-maize cropping pattern of Eastern India.

Organic manures are reported to release allelopathic phytochemicals after application to soil, which can reduce the weed emergence and weed seed mortality $[14,15]$. More specifically, neem seed powder significantly reduces the emergence of Striga weed [17]. By restricting the growth of predominant weeds, concentrated organic manures resulted in the lower nutrient uptake by total weed flora in maize. As such, the addition of organic manures enhanced the $\mathrm{N}$ uptake by maize grain in comparison to $\mathrm{N}$ uptake by maize plants grown under synthetic fertilizers. The suppression of weeds by organic manures and the increase in maize yield was more pronounced in the second year of study, due to the additive benefits of the organic manures in the same field. The yearly application of organic manures may deplete the weed seed in the soil seed bank over time. In addition, organic manure releases plant nutrients slowly to crops over time. Of the nutrients present in the manures, only $30 \%$ of the $\mathrm{N}$ and $\mathrm{P}$ may be released in the first year with a smaller proportion released in the following year $[49,50]$. The progressive mineralization and release of nutrients over time often results in better nutrient use efficiency than by the application of plant nutrients through inorganic fertilizers only [51]. The application of $50 \%$ of the recommended fertilizer through the inorganic source and the remaining $50 \%$ through poultry manure effectively reduced the weed density and growth, as well as significantly increasing the grain and stover yield of maize [52].

In this study, there was a negative linear relationship between the nutrient $(\mathrm{N}, \mathrm{P}$ and $\mathrm{K})$ uptake by weeds and the grain yield of the maize crop (Figure 1). With each unit $\left(\mathrm{kg} \mathrm{ha}^{-1}\right)$ of $\mathrm{N}, \mathrm{P}$ and $\mathrm{K}$ uptake by weeds, the grain yield of maize declined by 37, 283 and $427 \mathrm{~kg} \mathrm{ha}^{-1}$, respectively. In the presence of weed flora, crop growth can be adversely suppressed via competition with the maize for resource allocation [53]. Irrespective of the weed management strategies, maize biomass and yield was increased in weed management practices as compared to weedy control. The findings from this study indicate that the application of atrazine at $1.0 \mathrm{~kg} \mathrm{ha}^{-1}$ along with hoeing resulted in greater crop growth; similar findings are also reported by [54]. A greater nutrient accumulation by the maize plant was achieved with the weed management practice as compared to the weedy, and this may be due to the restriction of the biomass accumulation by weeds in different weed management treatments, which ultimately facilitates greater NPK accumulation. The nutrient uptake and accumulation in maize kernels results from the nutrient acquisition, especially in the reproductive growth period, as well as the magnitude or effectiveness of nutrient allocation during the vegetative growth phase.

A single weed management approach is not sufficient for the effective management of the diverse weed flora of a crop. The integration of two or more approaches results in better weed control efficiency than a single one [19,55]. Lakshmi [56] found that the PRE application of atrazine at $1.0 \mathrm{~kg} \mathrm{ha}^{-1}$ followed by the post-emergence application of halosulfuron methyl at $90 \mathrm{~g} \mathrm{ha}^{-1}$ resulted in the highest nutrient uptake by maize and the lowest by weeds. In this study, the integration of mechanical weeding with atrazine effectively managed the diverse weed flora of maize. In particular, hoeing or mechanical weeding controlled weeds, such as C. rotundus, which were not usually controlled with atrazine PRE [57]. The biomass accumulation by C. rotundus at 60 DAS was curtailed by 80 and $74 \%$ with the integration of hoeing with PRE-herbicide as compared to sole atrazine application in year 1 and year 2, respectively. The better management of diverse weed flora with atrazine followed by hoeing effectively diminished the weed growth and nutrient depletion by weeds, and eventually accelerated the growth of the maize plant, enhanced the nutrient uptake by the crop and ultimately enhanced the maize grain yield. 

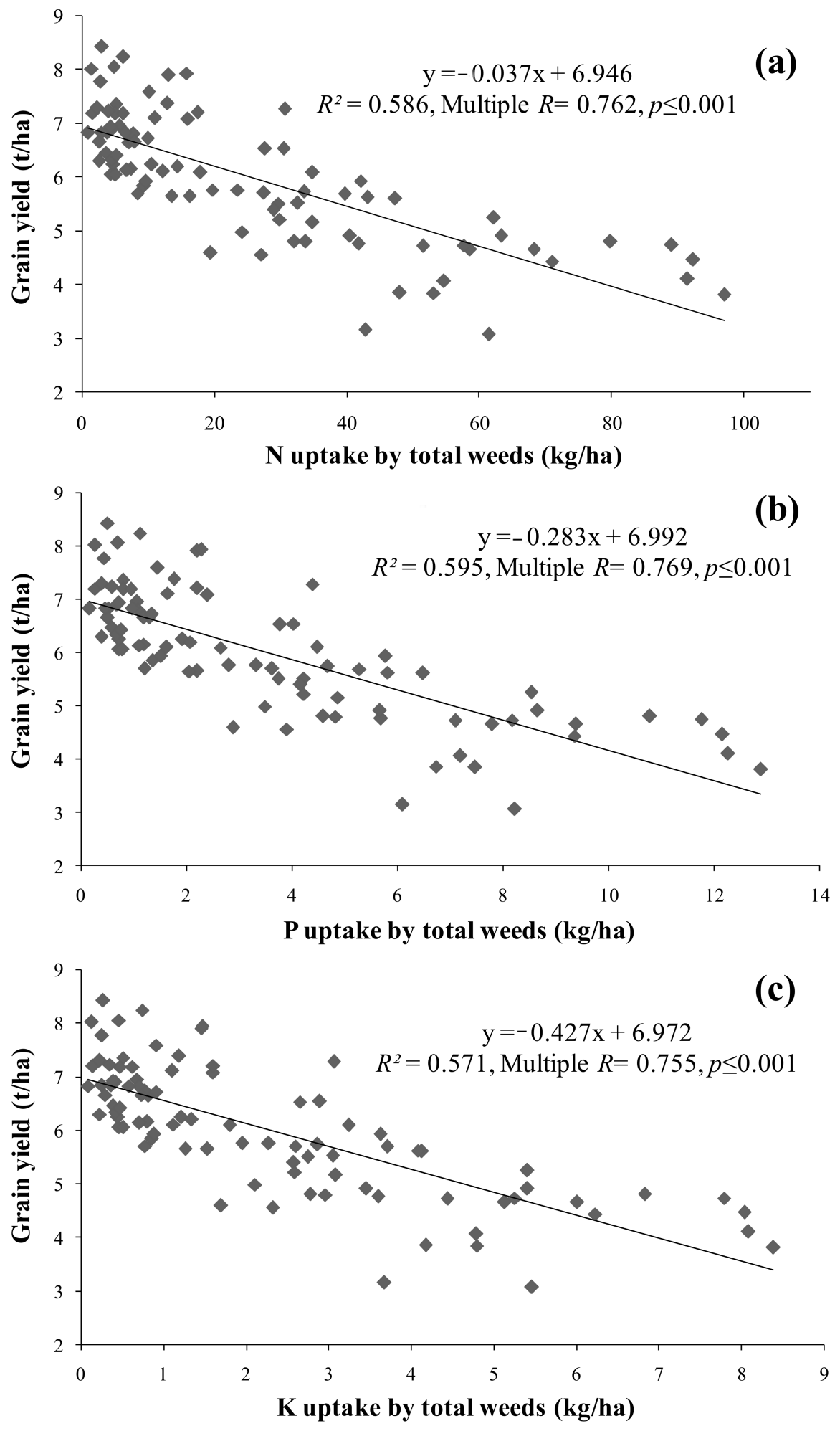

Figure 1. The relationship among $\mathrm{N}(\mathbf{a}), \mathrm{P}(\mathbf{b})$ and $\mathrm{K}(\mathbf{c})$ uptake by total weeds at $60 \mathrm{DAS}$ and the grain yield of maize.

\section{Conclusions}

The application of concentrated organic material effectively diminished the weed density as well as the growth of dominant weeds. The integration of nutrient and weed management practices significantly enhanced the N, P and K uptakes by the crop, as well as the yield of maize. Thus, the supplementation of $\mathrm{N}$ through BSM and the application of atrazine followed by hoeing augmented 
the growth and yield of the maize crop by suppressing the weeds, and gave a higher economic return for the producer.

Author Contributions: Conceptualization, D.G. and K.B.; methodology, D.G. and K.B.; software, S.S., N.K.D.; validation, M.S., K.B., and A.H.; formal analysis, D.G., S.S., A.D., B.P. and D.M.; investigation, D.G., S.S. and N.K.D.; resources, K.B. and A.D.; data curation, D.G., D.M., and B.P.; writing-original draft preparation, D.G., S.S., D.M. and A.H.; writing-review and editing, K.B., M.S., A.H., M.B., M.S., R.W.B., S.M., and P.O.; supervision, K.B.; project administration, K.B., R.W.B., M.B. and P.O.; funding acquisition, M.S., A.H., M.B., R.W.B., and P.O. All authors have read and agreed to the published version of the manuscript.

Funding: This research was funded by the 'Slovak University of Agriculture', Nitra, Tr. A. Hlinku 2, 94901 Nitra, Slovak Republic under the project 'APVV-18-0465 and EPPN2020-OPVaI-VA-ITMS313011T813'.

Acknowledgments: The authors would like to thank Hon'ble Vice-Chancellor, Bidhan Chandra Krishi Viswavidyalaya for providing resources to complete the trials.

Conflicts of Interest: The authors declare no conflict of interest. The funders had no role in the design of the study; in the collection, analyses, or interpretation of data; in the writing of the manuscript, or in the decision to publish the results.

\section{References}

1. IndiaStat. IndiaStat Data Base. Available online: www.indiastat.org (accessed on 1 July 2017).

2. Timsina, J.; Jat, M.L.; Majumdar, K. Rice-maize systems of South Asia: Current status, future prospects and research priorities for nutrient management. Plant Soil 2010, 335, 65-82. [CrossRef]

3. Rakshit, R.; Das, A.; Padbhushan, R.; Sharma, R.P.; Sushant; Kumar, S. Assessment of soil quality and identification of parameters influencing system yield under long-term fertilizer trial. J. Indian Soc. Soil Sci. 2018, 66, 166. [CrossRef]

4. Zhang, Y.; Chunsheng, H.; Jiabao, Z.; Deli, C. Nitrogenbalance in intensive agriculture in the north china plain. In Proceedings of the International Plant Nutrition Colloquium XVI, Davis, CA, USA, $26-30$ August 2009; Department of Plant Science, US Davis: Davis, CA, USA, 2009.

5. Jeyabal, A.; Kuppuswamy, G. Recycling of organic wastes for the production of vermicompost and its response in rice-legume cropping system and soil fertility. Eur. J. Agron. 2001, 15, 153-170. [CrossRef]

6. Triberti, L.; Nastri, A.; Giordani, G.; Comellini, F.; Baldoni, G.; Toderi, G. Canmineral and organic fertilization help sequestrate carbon dioxide in cropland? Eur. J. Agron. 2008, 29, 13-20. [CrossRef]

7. Alluvione, F.; Fiorentino, N.; Bertora, C.; Zavattaro, L.; Fagnano, M.; Chiarandà, F.Q.; Grignani, C. Short-term crop and soil response to C-friendly strategies in two contrasting environments. Eur. J. Agron. 2013, 45, 114-123. [CrossRef]

8. Grignani, C.; Zavattaro, L.; Sacco, D.; Monaco, S. Production, nitrogen and carbon balance of maize-based forage systems. Eur. J. Agron. 2007, 26, 442-453. [CrossRef]

9. Li, L.-J.; You, M.-Y.; Shi, H.-A.; Ding, X.; Qiao, Y.-F.; Han, X.Z. Soil CO2 emissions from a cultivated Mollisol: Effects of organic amendments, soil temperature, and moisture. Eur. J. Soil Biol. 2013, 55, 83-90. [CrossRef]

10. Melero, S.; Madejón, E.; Ruiz, J.-C.; Herencia, J.F. Chemical and biochemical properties of a clay soil under dryland agriculture system as affected by organic fertilization. Eur. J. Agron. 2007, 26, 327-334. [CrossRef]

11. Saha, P.K.; Ishaque, M.; Saleque, M.A.; Miah, M.A.M.; Panaullah, G.M.; Bhuiyan, N.I. Long-Term Integrated Nutrient Management for Rice-Based Cropping Pattern: Effect on Growth, Yield, Nutrient Uptake, Nutrient Balance Sheet, and Soil Fertility. Commun. Soil Sci. Plant Anal. 2007, 38, 579-610. [CrossRef]

12. Narwal, R.P.; Chaudhary, M. Effect of long-term application of FYM and fertilizer $\mathrm{N}$ on available $\mathrm{P}, \mathrm{K}$ and S content of soil. In Proceedings of the 18th World Congress of Soil Science, Philadelphia, PA, USA, 9-15 July 2006.

13. Tadesse, T.; Dechassa, N.; Bayu, W.; Gebeyehu, S. Effects of Farmyard Manure and Inorganic Fertilizer Application on Soil Physico-Chemical Properties and Nutrient Balance in Rain-Fed Lowland Rice Ecosystem. Am. J. Plant Sci. 2013, 4, 309-316. [CrossRef]

14. Hoagland, L.; Carpenter-Boggs, L.; Reganold, J.; Mazzola, M. Role of native soil biology in Brassicaceous seed meal-induced weed suppression. Soil Biol. Biochem. 2008, 40, 1689-1697. [CrossRef]

15. Abdulla, M.K.; Kumar, S. Phytotoxic Effect of Mustard Cake on Seed Germination and Seedling Growth of Crop and Weeds. Nat. Environ. 2014, 19, 132-136. 
16. Xuan, T.D.; Tsuzuki, E.; Hiroyuki, T.; Mitsuhiro, M.; Khanh, T.D.; Chung, I.-M. Evaluation on phytotoxicity of neem (Azadirachta indica. A. Juss) to crops and weeds. Crop Prot. 2004, 23, 335-345. [CrossRef]

17. Marley, P.S.; Shebayan, J.A.Y.; Aba, D.A.; Ideam, B.A. Possibilities for control of Striga hermonthica in Sorghum (Sorghum bicolor) using neem (Azadirachta indica) and parkia (Parkia biglobosa)-based products. Int. J. Pest Manag. 2004, 50, 291-296. [CrossRef]

18. Kaur, S.; Kaur, R.; Chauhan, B.S. Understanding crop-weed-fertilizer-water interactions and their implications for weed management in agricultural systems. Crop Prot. 2018, 103, 65-72. [CrossRef]

19. Ghosh, D.; Singh, U.P.; Brahmachari, K.; Singh, N.K.; Das, A. An integrated approach to weed management practices in direct-seeded rice under zero-tilled rice-wheat cropping system. Int. J. Pest Manag. 2017, 63, 37-46. [CrossRef]

20. Ghosh, D.; Singh, R.; Chander, S. Effect of nitrogen fertilizer and weed management practices on weed growth and crop yield of zero-till transplanted rice. Indian J. Weed Sci. 2018, 50, 287. [CrossRef]

21. Kumar, M.; Ghosh, D.; Singh, R. Effect of crop establishment and weed management practices on growth and yield of wheat. Indian J. Weed Sci. 2018, 50, 129. [CrossRef]

22. Ghosh, D.; Rathore, M.; Brahmachari, K.; Singh, R.; Kumar, B. Impact of burial and flooding depths on Indian weedy rice. Crop Prot. 2017, 100, 106-110. [CrossRef]

23. Gharde, Y.; Ghosh, D.; Singh, P.; Dubey, R.P. Fitting dose-response curve to identify herbicide efficacy and ED50 value in mixture. Indian J. Weed Sci. 2017, 49, 165. [CrossRef]

24. Eo, I.; Jo, O. Weed Infestation, Growth and Yield of Maize (Zea mays L.) as Influenced by Periods of Weed Interference. Adv. Crop Sci. Technol. 2017, 5, 267. [CrossRef]

25. Thobatsi, T. Growth and Yield Responses of Maize (Zea mays L.) and Cowpea (Vigna unguiculatea) in an Intercropping System. Master's Thesis, University of Pretoria, Pretoria, South Africa, 2009; p. 149.

26. Mimmo, T.; Bartucca, M.L.; Del Buono, D.; Cesco, S. Italian ryegrass for the phytoremediation of solutions polluted with terbuthylazine. Chemosphere 2015, 119, 31-36. [CrossRef]

27. Singh, R.; Ghosh, D.; Dubey, R.P.; Singh, V. Weed control in sesame with pre-emergence herbicides. Indian J. Weed Sci. 2018, 50, 91. [CrossRef]

28. Banerjee, H.; Garai, S.; Sarkar, S.; Ghosh, D.; Samanta, S.; Mahato, M. Efficacy of herbicides against canary grass and wild oat in wheat and their residual effects on succeeding greengram in coastal Bengal. Indian J. Weed Sci. 2019, 51, 246. [CrossRef]

29. Kundu, R.; Mondal, M.; Garai, S.; Banerjee, H.; Ghosh, D.; Majumder, A.; Poddar, R. Efficacy of herbicides on weed control, rhizospheric micro-organisms, soil properties and leaf qualities in tea plantation. Indian J. Weed Sci. 2020, 52, 160. [CrossRef]

30. Kumar, A.; Nandan, R.; Singh, K.K.; Ghosh, D. Integrated weed management in lentil (Lens culinaris) in calcareous alluvial soils of Bihar. Indian J. Agron. 2016, 61, 75-78.

31. Ghosh, D.; Singh, U.P.; Ray, K.; Das, A. Weed management through herbicide application in direct-seeded rice and yield modeling by artificial neural network. Span. J. Agric. Res. 2016, 14, e1003. [CrossRef]

32. Arias-Estévez, M.; López-Periago, E.; Martínez-Carballo, E.; Simal-Gandara, J.; Mejuto, J.-C.; García-Río, L. The mobility and degradation of pesticides in soils and the pollution of groundwater resources. Agric. Ecosyst. Environ. 2008, 123, 247-260. [CrossRef]

33. Magne, C.; Saladin, G.; Clement, C. Transient effect of the herbicide flazasulfuronon carbohydrate physiology in Vitis vinifera L. Chemosphere 2006, 62, 650-657. [CrossRef]

34. Boily, M.; Sarrasin, B.; Deblois, C.; Aras, P.; Chagnon, M. Acetylcholinesterase in honey bees (Apis mellifera) exposed to neonicotinoids, atrazine and glyphosate: Laboratory and field experiments. Environ. Sci. Pollut. Res. 2013, 20, 5603-5614. [CrossRef]

35. Van Der Meulen, A.; Chauhan, B.S. A review of weed management in wheat using crop competition. Crop Prot. 2017, 95, 38-44. [CrossRef]

36. O'Donovan, J.T.; McAndrew, D.W.; Thomas, A.G. Tillage and Nitrogen Influence Weed Population Dynamics in Barley (Hordeum vulgare). Weed Technol. 1997, 11, 502-509. [CrossRef]

37. Bouyoucos, G.J. Hydrometer method improved for making particle size analysis of soils. Agron. J. 1962, 54, 464-465. [CrossRef]

38. Day, P.R. Particle Fractionation and Particle-Size Analysis. Agron. Monogr. 2015, 545-567. [CrossRef]

39. Jackson, M.L. Soil Chemical Analysis; Prentice Hall of India Pvt. Ltd.: New Delhi, India, 1967; p. 498. 
40. Subbiah, B.; Asija, G.L. A rapid procedure for the estimation of available N in soils. Curr. Sci. 1956, 25, 259-260.

41. Olsen, S.R.; Cole, C.V.; Watanale, F.S.; Dean, L.A. Estimation of Available Phosphorus in Phosphorus in Soils by Extraction with Sodium Bicarbonate; United States Department of Agriculture: Washington, DC, USA, 1954.

42. Brown, A.J.; Warncke, D. Recommended Chemical Soil Test Procedures for the North Carolina Region; Dahnke, W.C., Ed.; North Dakota Agricultural Experimental Station Bulletin: Bismarck, ND, USA, 1988; pp. 15-16.

43. Ghosh, D.; Brahmachari, K.; Skalicky, M.; Hossain, A.; Sarkar, S.; Dinda, N.K.; Das, A.; Pramanick, B.; Moulick, D.; Brestic, M.; et al. Nutrients Supplementation through Organic Manures Influence the Growth of Weeds and Maize Productivity. Molecules 2020, 25, 4924. [CrossRef]

44. Singh, N.; Rajendran, R.A.; Shekhar, M.; Jat, S.L.; Kumar, R.; Kumar, R.S. Rabi Maize Opportunities \& Challenges. Tech. Bull. 2012, 9, 32.

45. GOI. Department of Agriculture Cooperation \& Farmers Welfare. Minimum Support Price for Kharif Crops. 2016. Available online: http://www.agricoop.nic.in/recentinitiatives/minimum-support-price-kharif-crops (accessed on 11 October 2018).

46. Babu, S.; Rana, D.S.; Rana, K.S.; Prasad, D. Effect of sunflower stover and nutrient management on productivity and nutrient uptake pattern of pigeon pea (Cajanus cajan) in pigeon pea-sunflower (Helianthus annuus) cropping system. Indian J. Agron. 2013, 58, 35-41.

47. Faostat. Statistical Databases and Data-Sets of the Food and Agriculture Organization of the United Nations. Available online: http://faostat.fao.org/default.aspx (accessed on 2 November 2020).

48. Rosegrant, M.R.; Ringler, C.; Sulser, T.B.; Ewing, M.; Palazzo, A.; Zhu, T.; Nelson, G.C.; Koo, J.; Robertson, R.; Msangi, S.; et al. Agriculture and Food Security Under Global Change: Prospects for 2025/2050; International Food Policy Research Institute: Washington, DC, USA, 2009.

49. Pinitpaitoon, S.; Bell, R.; Suwanarit, A. The significance of available nutrient fluxes in N and P budgets for maize cropping on a Rhodic Kandiustox: A study with compost, NP fertilizer and stubble removal. Nutr. Cycl. Agroecosyst. 2010, 89, 199-217. [CrossRef]

50. Pinitpaitoon, S.; Suwanarit, A.; Bell, R.W. A framework for determining the efficient combination of organic materials and mineral fertilizer applied in maize cropping. Field Crops Res. 2011, 124, 302-315. [CrossRef]

51. Xu, H.L.; Wang, R.; Xu, R.Y.; Mridha, M.A.U.; Goyal, S. Yield and quality of leafy vegetables grown under organic fertilization. Acta Hortic. 2003, 627, 25-33. [CrossRef]

52. Nagavani, A.V.; Subbian, P. Effect of Integrated Nutrient Management (INM) on weeds and yield of hybrid maize. Curr. Biotica 2015, 8, 432-436.

53. Malviya, A.; Singh, B. Weed dynamics, productivity and economics of maize (Zea mays) as affected by integrated weed management under rainfed condition. Indian J.Agron. 2007, 52, 321-324.

54. Rao, C.H.R.; Prasad, P.V.N.; Venkateswarlu, B. Assessment of different herbicides on yield and economics of kharif maize (Zea mays L.). Intern. J. Agric. Sci. Res. 2016, 6, 409-414.

55. Sunitha, N.; Reddy, P.M.; Reddy, D.S. Influence of planting pattern and weed control practices on weed growth, nutrient uptake and productivity of sweet corn (Zea mays L.). Crop Res. 2011, 41, 13-20.

56. Lakshmi, P.V.; Luther, M.M. Studies on influence of herbicides on nutrient uptake and yield in maize. Int. J. Farm Sci. 2017, 7, 37-39.

57. Singh, S.; Walia, U.S.; Kaur, R.; Singh, S.L. Chemical Control of Cyperus rotundus in Maize. Indian J. Weed Sci. 2010, 42, 189-192.

Publisher's Note: MDPI stays neutral with regard to jurisdictional claims in published maps and institutional affiliations.

(C) 2020 by the authors. Licensee MDPI, Basel, Switzerland. This article is an open access article distributed under the terms and conditions of the Creative Commons Attribution (CC BY) license (http://creativecommons.org/licenses/by/4.0/). 